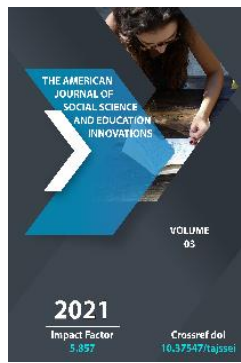

\title{
The First American Journalist To Come To The Khiva Khanate
}

\author{
Shokhrukhbek Farkhadovich Allanazarov \\ Master Student, Tashkent State University Of Oriental Studies, Uzbekistan
}

Journal Website:

https://theamericanjou

rnals.com/index.php/ta

jssei

Copyright: Original content from this work may be used under the terms of the creative commons attributes 4.0 licence.

\section{ABSTRACT}

The article is about the life and work of McGahan, the first American journalist to visit the Khiva Khanate in 1873 , and his work during his time in the Khiva Khanate, which provides new information about the Russian invasion.

\section{KEYWORDS}

Khiva Khanate, Russian Empire, Invasion, MacGahan, Kaufman, Muhammad Rahimkhan II, Gandhimiyon, Treaty.

\section{INTRODUCTION}

In the 19th century, many travelers visited the khanates of Central Asia and wrote interesting information about the population, social life and history of the region. The Khiva Khanate and the process of its conquest by the Russians aroused great interest in the Western public. McGahan, an American journalist and researcher, visited the Khiva Khanate directly during the Russian occupation and covered the occupation of Khiva and the signing of an agreement between the two countries. In this regard, his data can be considered as an important valuable source in the coverage of the history of this period. Who was MacGahan? What happened before he reached the Khiva khanate?

Januarius Aloysius MacGahan (1844-1878) was an American journalist best known for his coverage of wars in various parts of the world. He has worked for the New York Herald and the Daily News in London. 
MacGahan was born on June 12, 1844, in New Lexington, Ohio, United States. January's father died when he was 7 years old. He started working on neighboring farms to support his family. At the age of 17 , he moved to Huntington, Indiana, where he worked as a salesman and teacher. In early 1864, MacGahan moved to St. Louis, where he worked for a time as an accountant for the Union Pacific Railroad. In St. Louis, he meets the hero of the Civil War, Irish General Philip Sheridan of Irish descent. General Sheridan, who had a beneficial effect on the young man's further development, persuaded him to go to Europe on law.[1]

\section{THE MAIN FINDINGS AND RESULTS}

In December 1868, MacGahan left for Brussels. MacGahan failed to become a lawyer, but he soon discovered the ability to learn foreign languages by mastering German and French. In 1870, the Franco-Prussian War broke out and General Sheridan helped MacGahan get a job as a war correspondent in the London office of the New York Herald. In 1871, January MacGahan became a correspondent for the New York Herald in St. Petersburg. He quickly mastered the Russian language and became acquainted with Russian aristocrats. In 1873 he met his future wife Varvara Nikolaevna Yelagina, who came from an old aristocratic family. MacGahan, knowing that the Russian army was invading the Khiva khanate, crossed the Kyzylkum on horseback despite the ban, and in 1873 witnessed the surrender of Khiva. Here he meets Colonel Mikhail Skobelev, whose friendship lasts for the rest of his life. He describes his experiences in the Khiva khanate in detail in his book "The Military Events in Oxus and the Fall of Khiva". This work was published in 1874 in London and in 1875 in Moscow.[2]

The issue of Russia's invasion of the Khiva Khanate was covered by many foreign historians and military sources in the late 19th century. One of them was the American journalist Arthur Januarius MacGahan, who was in the Russian army to take part in the Russian military expedition to the Khiva Khanate and published a detailed diary of his experiences in Khiva.[3] This work has been published many times in English. In 1876, the work was published for the fourth time in London with many paintings and maps. The work consists of 3 parts. Each section consists of chapters. The content of the work is as follows:

Part 1. Life in the Kyzylkum (21 chapters);

Part 2. The fall of Khiva. (20 chapters);

Section 3. The Turcoman campaign. (14 chapters).[4]

Before the Russian army, led by General K.P. von Kaufmann, reached Khiva, the city was occupied by troops led by Colonel N.A. Veryovkin, who was marching in the direction of Orenburg. At the same time, MacGahan arrives in Khiva, and his first task is to see the city. He was fascinated by the majesty, beauty and architecture of this city. The residence of General von Kaufmann, the Commander-inChief of the Russian troops involved in the occupation of Khiva, was located in a field in the village of Gandimiyon, which belonged to Otajon Tora, the younger brother of Khiva Khan Muhammad Rahimkhan. MacGahan will also be living here for 3 months. He befriended Colonel M.D. Skobelev of the Russian Army and learned from him documents about the life of the oasis.[5]

According to A.J. MacGahan, the khan's uncle, Sayyid Amir ul-Umaro, served as a pro-Russian in the khanate, that is, he was in favor of good neighborly relations with Russia. On the eve of the Russian army's attack on the Khiva khanate, Matniyaz's office also supported the idea. However, Matmurad Devonbegi, who 
was the mehtar in the khanate, was completely against this idea.[6] The existence of an internal struggle between the officials, the lack of a unified opinion, prevented the proper organization of the defense, as a result of which on May 23, 1873 the advanced detachment of the Russian army did not fire a single shot at the fortress of Hazarasp. occupied. However, the protection of this fortress was entrusted to the khan's uncle Sayyid Amir ul-Umar. He left Hazarasp and went to Khiva.[7]

In his book, A.J. MacGahan mentions GovernorGeneral K.P. von Kaufman. He provided the full text of Kaufman's letter to Khiva Khan Muhammad Rahimkhan II. According to him, K.P. Kaufman stated that he would not kill the khan, nor would he exile him to Siberia, but would transfer him back to the khan's throne under certain conditions. The author describes in detail the khan's visit to K.P. von Kaufman with Murad Tora, Matmurad Devonbegi and other relatives.[8]

Part 2 of MacGahan's work, Chapter 13, is entitled "A Conversation with the Khan (Kaufman and the Khan)." MacGahan's book describes the first direct meeting between the khan of Khiva and Kaufman in an interesting way, and as a witness to the conversation between them, he wrote: "On June 14, the khan returned to Khiva with his followers and was brought before the conqueror. Kaufman received him under a pine tree in front of the tent. There was a high brick platform with carpets, tables and chairs. The first conversation between Kaufman and the khan took place on this platform. ... The khan humbly entered his garden with about twenty of his followers, and when he reached the end of the short alley of young poplars leading to General Kaufman's tent, he dismounted from his great horse and placed his brother-in-law in front of him. He took off his hat and bowed as he approached..." [9] This marked the beginning of negotiations between General Kaufman and Khiva Khan Muhammad Rahimkhan II.

A.J. MacGahan also spoke about the 18 -article agreement between Khiva and Russia in the village of Gandimiyon: was not committing military acts. The lands on the right bank of the Amu Darya were transferred to Russia, and in 1874 the Amudarya branch of the GovernorGeneral of Turkestan was established.[10]

According to the Regulations on the Administration of the Turkestan Province of 1886, the head of the Amudarya branch was the head of the uyezd and supervised the activities of the khan. Relations between Russia and the Khiva Khanate were conducted through the head of the district. A.J. MacGahan also clearly indicated the information on how to pay the compensation of two million two hundred thousand soums to the Russian Empire by the khan of Khiva Muhammad Rahimkhan II.

In September 1873, together with the Russian army, A.J. MacGahan returned first to Orenburg and then to St. Petersburg. Developments in Central Asia have been the focus of attention not only in Russia but around the world. This was especially true of the British, who were politically dominant in Asia. For this reason, A.Ya. MacMahan's "Military Activities on Oxus and the Field of Khiva". (Translation from English). - M., 1875. -304 C. his book was quickly published in 1874 in English. In 1875, the book was translated into Russian and published in large numbers by the Russkiy Vestnik Association in Moscow. The book is enriched by the inclusion of pencil drawings by the famous Russian artist V.V .Vereshagin and lieutenant Fedorov, who took part in the Khiva march. 
The translation and publication of A.J. MacMahan's book in Turkish increased the opportunities for Turkic-speaking peoples to use this work.[11]

In his memoirs, MacGahan also described what he saw in the palace of the Khiva Khanate. MacGahan, for example, described in detail the treasures of the Khiva palace that he had seen with his own eyes. According to him, in the two adjoining rooms of the khan's palace, he saw a large pile of various weapons and military armor, including a "shield of knights with the image of a lotus flower", ornate ancient oriental weapons, Khorasan swords, Iranian swords and precious-enveloped Afghan daggers with stones." The second room contained mostly books, as well as bows and arrows and many ancient utensils. There are more than a thousand Chinese porcelain items from the 17th to the 19th centuries alone, and these rare items have become prey for Russian officers, " [12] he said.

\section{CONCLUSION}

In conclusion, MacGahan was the first American journalist to visit the Central Asian region, particularly the Khiva Khanate. Through his memoirs we can learn about the process of conquest of Khiva by the Russian Empire, the events of that time in the khan's palace, the social life of the khanate, the relationship between the colonial Russian empire and the khan's government. Through MacGahan we learn the first research of foreigners on the process of the conquest of the Khiva khanate.

\section{REFERENCES}

1. Иванян Э. А. Макгэхен Джануариус Алойзиус. - Энциклопедия российскоамериканских отношений. XVIII-XX века. — М.: Международные отношения, 2001. - C.696.
2. Теодор Делчев Димитров. Януари Макгахан 1844-1878. Биография, документы и материалы. - София: Наука и искусство, 1977. - С.214.

3. Mac Gahan, J.A. Campaigning on the Oxus, and the fall of Khiva. - London: Sampson Low, 1874. - P.547.

4. Mac Gahan, J.A. Campaigning on the Oxus, and the fall of Khiva. With map and numerous illustrations. Fourth and cheaper edition. — London: Sampson Low, 1876. P.508.

5. Махмудов М. Хоразм тарихидан лавхалар. - Урганч, 1998. - Б.70.

6. Mac Gahan, J.A. Campaigning on the Oxus, and the fall of Khiva. - London: Sampson Low, 1874. - P.289.

7. Mac Gahan, J.A. Campaigning on the Oxus, and the fall of Khiva. - London: Sampson Low, 1874. - P. 195, 201, 289.

8. Mac Gahan, J.A. Campaigning on the Oxus, and the fall of Khiva. - London: Sampson Low, 1874. - P.350.

9. Mac Gahan, J.A. Campaigning on the Oxus, and the fall of Khiva. With map and numerous illustrations. Fourth and cheaper edition. - London: Sampson Low, 1876. P. 274.

10. Mac Gahan, J.A. Campaigning on the Oxus, and the fall of Khiva. - London: Sampson Low, 1874. - P.416-420.

11. Mac Gahan. I.A. Hive seyahatnamesi ve tarixi / hazirlayanlar Prof. Dr. Ismail Aka, Dr.Mehmet Ersan. - Izmir: Akademi Kitabevi, 1995. - P.270.

12. Mac Gahan, J.A. Campaigning on the Oxus, and the fall of Khiva. - London: Sampson Low, 1874. - P.411. 